\title{
SYNTHESIS AND CYTOTOXIC ACTIVITY OF 2,5-BIS(4- BORONIC ACID)BENZYLIDINE CYCLOPENTANONE ON HER2 OVEREXPRESSED-CANCER CELLS
}

\author{
Rohmad Yudi Utomo ${ }^{1}$, Herwandhani Putri ${ }^{1}$, Pudjono ${ }^{2}$, Ratna Asmah Susidarti ${ }^{2}$, Riris \\ Istighfari Jenie ${ }^{1,2}$, Edy Meiyanto ${ }^{1,2} *$
}

${ }^{1}$ Cancer Chemoprevention Research Center, Faculty of Pharmacy, Universitas Gadjah Mada,

Sekip Utara 55281,

Yogyakarta, Indonesia

2Departement of

Pharmaceutical Chemistry,

Faculty of Pharmacy,

Universitas Gadjah Mada,

Sekip Utara 55281,

Yogyakarta, Indonesia

Submitted: 03-02-2017

Revised: 03-04-2017

Accepted: 15-04-2017

*Corresponding author

Edy Meiyanto

Email:

meiyan_e@ugm.ac.id

\begin{abstract}
Development of chemotherapeutic agent and boron carrying pharmaceutical based on HER2 specific targeted is important due to its role in enhancing cancer progression. The purpose of this study is to synthesize curcumin analogue, namely Pentagamaboron-0 (PGB-0) or 2,5-bis(4-boronic acid)benzylidine cyclopentanone, and to explore the cytotoxic activity on HER2 overexpressed-cancer cells. MCF-7/HER2 was used as a model of HER2 overexpressed-cancer cells and NIH3T3 as normal cells. PGB-0 bound to ATP binding site of HER2 and EGFR based on molecular docking study. PGB-0 was synthesized resulting in $33 \%$ yield and was confirmed by IR, ${ }^{1} \mathrm{HNMR},{ }^{13} \mathrm{CNMR}$ and Mass spectroscopy. Based on MTT assay PGB-0 decreased cells viability on MCF-7/HER2 cells with IC $_{50}$ value of $270 \mu \mathrm{M}$ but performed no effect on NIH3T3 cells. Cell cycle analysis revealed that PGB-0 increased sub-G1 accumulation. PGB-0 decreased HER2 expression in a dose-dependent manner. We conclude that the new compound PGB-0 inhibits cell growth through cell death induction and decreased HER2 expression. Thus, PGB-O is potential to be developed as a chemotherapeutic agent and boron carrying pharmaceutical targeted on the HER2 receptor.
\end{abstract}

Key words: Synthesis of PGB-0, MCF7/HER-2, cytotoxic

\section{INTRODUCTIONS}

HER2 is a transmembrane protein that is overexpressed in most human solid tumors such as breast, ovarian, endometrial, colon, and non-small cell lung cancer, prostate, and cervical cancer (English et al., 2013). Moreover, more than $20 \%$ cases of breast cancer are related with overexpression of HER2 protein and correlated with a worse survival of patients (Gibbs, 2000). The HER2 receptor is normally expressed in healthy cells and is responsible for the regulator in cell growth and differentiation (Yakes et al., 2002). Thus, HER2 signaling becomes an interesting field to develop a molecular targeted therapy for cancer.

Several chemotherapeutic agents targeted on HER2 receptor are developed. Trastuzumab is found to be the first antibody targeting HER2. However, $70 \%$ of patients who prolonged use of trastuzumab show a resistance phenomenon leading to a progression of metastatic cancer due to the increasing of EGFR expression (Meiyanto et al., 2011; Vu and Claret, 2012). To overcome this resistance phenomenon, gefitinib and WZ4002, a known EGFR inhibitor are developed. However, the use of gefitinib and WZ4002 lead to a new EGFR mutation causing ineffectiveness therapy. Further, lapatinib is introduced to overcome all of the resistance phenomena. Lapatinib effectively works both on tyrosine kinase EGFR and HER2 as well as ER receptor (D'Amato et al., 2015). The finding of lapatinib becomes a new insight to develop a chemotherapeutic targeted as a dual inhibitor not only targeted to the HER2 receptor but also EGFR. Recently, several cases reported that some patients were resistant to lapatinib treatment (D'Amato et al., 2015). Therefore, development of an ideal chemotherapeutic agent targeted on both EGFR and HER2 receptor needs to be explored thoroughly. 
<smiles>O=C1/C(=C/c2ccc(B(O)O)cc2)CC/C1=C\c1ccc(B(O)O)cc1</smiles>

Figure 1. Chemical Structure of 2,5-bis(4boronic acid)benzylidine cyclopentanone or Pentagamaboronon-0 (PGB-0).

Curcumin is a potential candidate of a chemotherapeutic agent to overcome the resistance phenomena on cancer due to its potency as tyrosine kinase inhibitor, including HER2 (Hong et al., 1999). However, curcumin is unstable at $\mathrm{pH}$ above 6.5 caused by its active methylene group (Sardjiman et al., 1997). Pentagamavunon-0 (PGV-0) and Pentagamavunon-1 (PGV-1) are developed by modifying the active methylene groups into cyclopentanone to overcome curcumin instability. The previous study showed that curcumin, PGV-0, and PGV-1 possess cytotoxic effect and inhibit $\mathrm{NF} \varkappa \mathrm{B}$ activation in vitro in MCF-7 breast cancer cells, as well as interact with the HER2 receptor in silico (Meiyanto et al., 2014). The interaction between HER2 receptor with PGV-0 and PGV-1 is mediated through the $\mathrm{H}$-bond between $\mathrm{O}$ atom on carbonyl group of PGV-0, and PGV-1 with $\mathrm{N}$ atom of Leu846 from the HER2 receptor. Hence, the carbonyl group on curcumin analogues is an essential part of the HER2 inhibitory activity. In order to develop curcumin analogues as boron carrying pharmaceuticals for boron neutron captured therapy (BNCT) application, 2,5bis(4-boronic acid)benzylidine cyclopentanone or Pentagamaboronon-0 (PGB-0) (Figure 1) is designed by modifying the hydroxyl group on benzene system into boronic acid and the using of cyclopentanone structure to maintain the potential binding of PGB-0 on HER2 receptor. In this study, we synthesize a new curcumin analog, PGB-0, and explored the cytotoxic activity on HER2 overexpressed-cancer cells as a candidate of chemotherapeutic agent and boron carrying pharmaceuticals targeted on the HER2 receptor.

\section{MATERIAL AND METHODS \\ Molecular docking, PLANTS}

Molecular docking was performed by Protein-Ligand Ant System (PLANTS) 1.1 software. The structure of EGFR (PDB ID: 1XKK) and HER2 (PDB ID: 3PP0) proteins were downloaded from PDB. YASARA (http://www.yasara.org/viewdl.htm) was used for protein preparation and MarvinSketch (http://www.chemaxon.com/marvin/downloa d-user.html) for ligand preparation. Visualization 2D and 3D performed by MOE 2010 software (Licensed by Faculty of Pharmacy, Universitas Gadjah Mada).

\section{Synthesis of 2,5-Bis(4-Boronic Acid) Benzylidine Cyclopentanone}

Eighty $\mu \mathrm{L}$ of cyclopentanone (Sigma) and $2 \mathrm{~mL}$ of $\mathrm{NaOH}$ (Merck) $10 \%$ were mixed in $5 \mathrm{~mL}$ of ethanol (Merck). Three hundred $\mathrm{mg}$ of 4-formylphenyl boronic acid (Sigma) was added then the mixture was stirred at $0^{\circ} \mathrm{C}$ for $30 \mathrm{~min}$. After settling for $1 \mathrm{~h}$, the mixture was neutralized by adding $\mathrm{HCl} 10 \%$ dropwise. The solid material was washed with ethanol:water 1:1 and filtered. The melting point of the compound was determined by Buchi instrument. Thin layer chromatography experiment was performed by using Silica Gel $60 \mathrm{GF}_{254}$ (Merck) and mobile phase methanol:chloroform 3:1 with detection by UV light. HPLC analysis was conducted by C18 column (chromosorb) and mobile phase acetonitrile:water (40:60) with UV detector at wavelength $254 \mathrm{~nm}$. The structure elucidation was carried out by using ${ }^{1} \mathrm{H}$ NMR and ${ }^{13} \mathrm{C}$ NMR (JEOL DELTA $500 \mathrm{MHz}$ ), IR spectrophotometry (Perkin-Elmer), and MS (Shimadzu).

\section{Cell culture}

MCF-7/HER2 was kindly gifted from Prof. Yoshio Inouye (Departement of Surgery, Toho University School of Medicine, Japan) through Prof. Masashi Kawaichi (Laboratory of Gene Function in Animals, NAIST, Japan). The cells NIH3T3 was kindly given by Prof. Masashi Kawaichi (Laboratory of Gene Function in Animals, NAIST, Japan). Cells were grown in Dulbecco's Modified Eagles Medium (DMEM) high glucose (Sigma) supplemented with 10\% FBS 
(Sigma), HEPES, sodium bicarbonate, 1.5\% Penicillin-Streptomycin and $0.5 \%$ Fungizone (Gibco). Cells were incubated at $37^{\circ} \mathrm{C}$ with $5 \%$ $\mathrm{CO}_{2}$.

\section{Cytotoxicity assay}

Cells were seeded in 96-well plates with $10^{4}$ cells/well. After $24 \mathrm{~h}$ incubation with PGB0 with various concentrations, the culture medium was removed and cells were washed in PBS (Sigma). Then, cells were incubated with $0.5 \mathrm{mg} / \mathrm{mL}$ MTT (Biovision) in $100 \mu \mathrm{L}$ culture medium each well for $4 \mathrm{~h}$. MTT reaction was stopped by SDS reagent $(10 \%$ Sodium dodecyl sulfate (Merck) in $\mathrm{HCl} 0.01 \mathrm{~N}$ (Merck) and was incubated overnight. The absorbance was measured by ELISA reader (Bio-Rad) at a wavelength of 595nm (Mosmann, 1983).

\section{Cell Cycle Distribution Analysis}

An amount of $5 \times 10^{3}$ cells/well cells were distributed to 6-well plate in DMEM medium. After $24 \mathrm{~h}$ incubation, cells were treated with PGB-0 1/2 IC $50(135 \mu \mathrm{M})$ and PGB$0 \mathrm{IC}_{50}(270 \mu \mathrm{M})$. Following $24 \mathrm{~h}$ treatment, cells were trypsinized and centrifuged with speed $365 \mathrm{~g}$ for $3 \mathrm{~min}$. Cell pellets were collected then were washed with a buffer solution as described by the manufacturer (BD Cycletest ${ }^{\mathrm{TM}}$ Plus DNA Kit; BD Biosciences, San Jose, USA). The treated cells suspension then was subjected to FACS Calibur (BD Bioscience) flowcytometer.

\section{Immunoblotting}

MCF-7/HER2 cells $\left(1 \times 10^{4}\right.$ cells $)$ were incubated in tissue culture dish and was treated with PGB-0 $(50 \mu \mathrm{M}$ and $150 \mu \mathrm{M})$ for $24 \mathrm{~h}$. Total protein cell lysates were prepared by using radioimmunoprecipitation assay (RIPA) buffer (Santa Cruz \#sc-364162) on ice. The cells suspension was sonicated and was centrifuged at $16000 \mathrm{~g}$ for $20 \mathrm{~min}$ at $4^{\circ} \mathrm{C}$. The protein samples were denatured in $5 \mathrm{x}$ sample buffer and were subjected to $10 \%$ SDS-polyacrylamide gel electrophoresis. The separated proteins were transferred into PVDF membrane followed by blocking with 5\% skim milk powder $(\mathrm{w} / \mathrm{v})$ in TBS $(20 \mathrm{mM}$ Tris and $133 \mathrm{mM}$ $\mathrm{NaCl}, 1 \mathrm{M} \mathrm{HCl}$ ) with $20 \%$ Tween 20 for $1 \mathrm{~h}$ at room temperature. The membrane was probed using primary antibodies as follows: HER2 antibody (Santa Cruz \#sc-52349) and $\alpha$-tubulin antibody (Santa Cruz \#sc-32293) overnight at $4^{\circ} \mathrm{C}$ followed by HRP-secondary antibodies mouse (Cell signaling \#7076) for $1 \mathrm{~h}$ at room temperature and was visualized by Amersham ECL Prime (\#RPN2232).

\section{Analysis}

Cytotoxicity study was analyzed by determining $\mathrm{IC}_{50}$ value. Cell cycle distribution was acquired by using Modfit LT 4.1.7. Method validation of molecular docking was conducted by measuring Root Mean Square Distances (RMSD) heavy atom ligand with copy ligands. If RMSD value higher than $2.0 \AA$ means that the molecular docking method is valid. The affinity of the compound was evaluated by identifying fPLP score. The lower $f_{\text {PLP }}$ score showed higher affinity of the binding and vice versa.

\section{RESULTS AND DISCUSSION Molecular Docking Study of PGB-O on EGFR and HER2}

Table I. fPLP Score of PGB-0 on EGFR and HER2

\begin{tabular}{ccc}
\hline \multirow{2}{*}{ Ligand } & EGFR RMSD: & HER2 RMSD: \\
& $\mathbf{1 . 9 1}$ & $\mathbf{0 . 9 5}$ \\
\hline Lapatinib & -150.04 & -119.55 \\
Curcumin & -88.83 & -96.51 \\
PGB-0 & $-82,20$ & -82.37 \\
\hline
\end{tabular}

Our main purpose of this research is to develop a new compound having cytotoxic activites to specific cancer cells especially HER2 overexpressed cells. Firstly, we used molecular docking to construct our hypotesis regarding the spesific activities of our candidates to the target protein. We obtained that PGB- 0 possessed potential candidate beside the other compounds (data not sown). Validation result showed molecular docking protocol was valid with RMSD value $<2 \AA$ (Table I). f f PLP score of PGB-0 was higher than lapatinib and curcumin on (Table I). However, PGB-0 possessed shorter binding distance than lapatinib at Thr 862 on the HER2 receptor (Table II). Compared to curcumin, PGB-0 also possessed more binding amino acid residues (Figure 2). 
Table II. Binding Interaction of Ligand on HER2

\begin{tabular}{ccccc}
\hline Ligand & Ligand Atom & Residue & Binding Type & Distance \\
\hline \multirow{5}{*}{ Lapatinib } & N & Leu 846 & H-don & 2.83 \\
& N & Ser 907 & H-don & 1.14 \\
& N & Thr 911 & H-don & 2.96 \\
& O & Ser 783 & H-acc & 1.62 \\
& O & Ser 783 & H-acc & 2.98 \\
& N & Thr 862 & H-acc & 2.80 \\
& O & Thr 862 & H-acc & 3.02 \\
Curcumin & O & Thr 911 & H-acc & 2.89 \\
& O & Leu 806 & H-acc & 2.03 \\
PGB-0 & O & Lys 860 & H-don & 2.53 \\
& O & Glu 914 & H-don & 1.05 \\
& O & Ala 848 & H-acc & 2.19 \\
& O & Thr 862 & H-acc & 2.47 \\
\hline
\end{tabular}

Table III. Binding Interaction of Ligand on EGFR

\begin{tabular}{ccccc}
\hline Ligand & Ligand Atom & Residue & Binding Type & Distance \\
\hline Lapatinib & O & Arg 841 & H-acc & 2.20 \\
& O & Glu 906 & H-don & 2.61 \\
Curcumin & O & Cys 775 & H-acc & 2.81 \\
& O & Glu 906 & H-don & 2.21 \\
\hline
\end{tabular}

PGB-0 interacts on the same amino acid residue with curcumin (Glu 906) and possessed a shorter bonding distance on EGFR receptors. However, when compared with lapatinib, PGB-0 bond on different amino acids and a longer bonding distance. (Table 3). Based on the result, we predicted that PGB-0 possibly bound to ATP-binding site of HER2 and EGFR with different binding properties compared to lapatinib and curcumin. Therefore, PGB-0 is a potential candidate of chemotherapeutic agent targeted on HER2 and EGFR.

\section{Synthesis of PGB-0}

Based on the molecular docking results, PGB-0 possesed comparable affinity on EGFR and HER2 with lapatinib and curcumin, therefore in the next step we synthesize PGB-0. In order to obtain the PGB-0 compound in high purity, we performed several synthesis optimizations (data not shown). Disconnection analysis of PGB-0 showed that PGB-0 predicted to be synthesized by reacting 4formylphenylboronic acid and cyclopentanone based on aldol condensation reaction (Scheme 1). PGB-0 compound was attained $33 \%$ yield. HPLC analysis showed that the purity of product was observed on 4 min with a high percentage $(95 \%)$ while the starting material 4-formylphenyl boronic acid was observed in low percentage at Rt of $2 \mathrm{~min}(5 \%)$ (Figure 3). The hRf of the product based on the experiment was 75 . The product profile was described as follows: $\mathrm{mp}>200^{\circ} \mathrm{C},{ }^{1} \mathrm{H}-\mathrm{NMR}$ $\left(\mathrm{CD}_{3} \mathrm{OD}\right): \delta 3.17$ (s, J=3.27, 4H, C- $\mathrm{CH}_{2}-\mathrm{CH}_{2-}$ C), $4.7(\mathrm{~s}, \mathrm{~J}=0.68,1 \mathrm{H},-\mathrm{OH}), 7.5(\mathrm{~s}, \mathrm{~J}=1.75,2 \mathrm{H}$, ), 7.6 (s, J=3.14, 4H, -CH-CH-CH-CH-), 7.7 (s, $\mathrm{J}=1.23,2 \mathrm{H},-\mathrm{CH}-\mathrm{C}-$ ), and 7.8 (s, $\mathrm{J}=1,1 \mathrm{H},-\mathrm{C}-$ $\mathrm{CH}-\mathrm{C}) \cdot{ }^{13} \mathrm{C}-\mathrm{NMR}\left(\mathrm{CD}_{3} \mathrm{OD}\right): \delta 27.7\left(\mathrm{~s},-\mathrm{CH}_{2}\right)$, 131 (s, -C-B-), 135 (s, -CH-), 135.1 (s, -CH-C-), 135.4 (-C-CH-), and 139 (s, -C-C=O-); IR ( $\mathrm{KBr}$ film) $\mathrm{cm}^{-1}: 1620(\mathrm{C}=\mathrm{O}), 3363(\mathrm{OH}), 1689$ ( $\mathrm{C}=\mathrm{C}$ alkene), 1550 ( $\mathrm{C}=\mathrm{C}$ aromatic), $624(\mathrm{C}-\mathrm{H}$ alkene). MS of the product was found 347.14, calculated 347.97. 

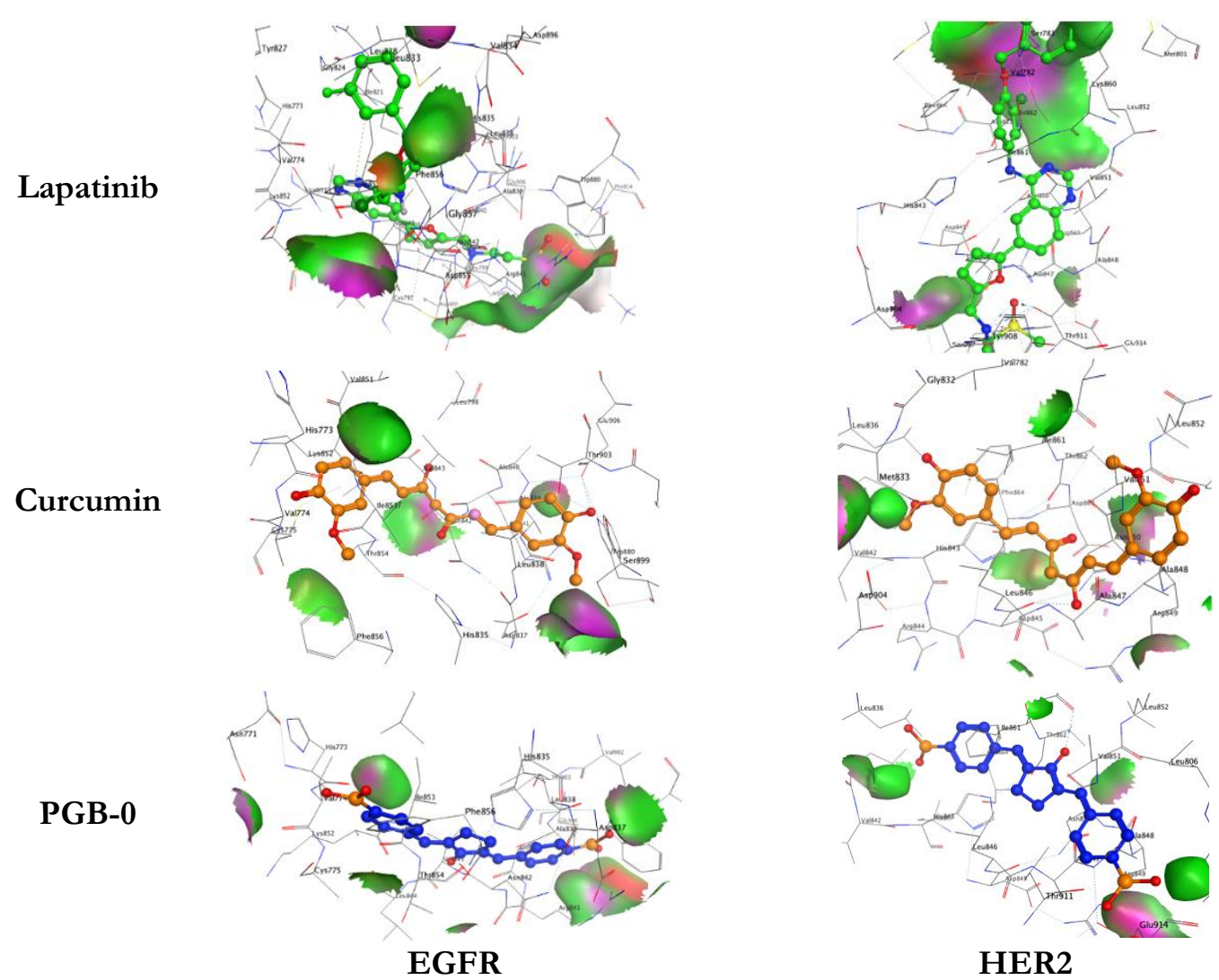

Figure 2. Visualization of ligand interaction on EGFR and HER2. The representative pose of lapatinib, Curcumin, and PGB-0. All ligand is depicted as balls and sticks. Green and purple cavity represent polar and hydrophobic interaction. Molecular Interaction was performed using MOE.

A<smiles>O=C1CCC(Cc2ccc(O)cc2)CC1CC1CCC(Cc2ccc(O)cc2)CC1</smiles>

B

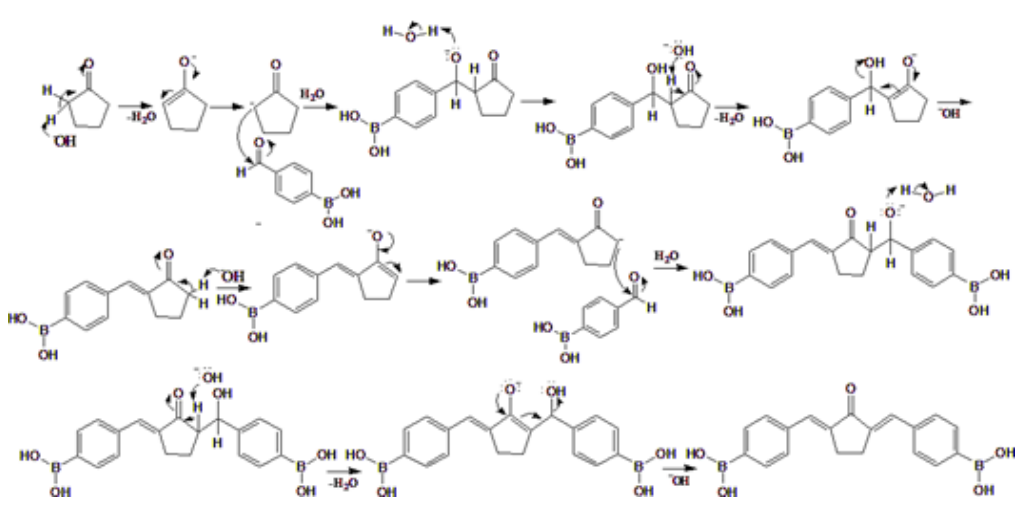

Scheme 1. (A) Disconnection analysis of PGB-0 (i). PGB-0 was synthesized by reacting cyclopentanone (ii) and 4-formylphenyl boronic acid (iii) by aldol condensation reaction. (B) Reaction Mechanism of PGB-0. Cyclopentanone possessed as nucleophile while 4-formylphenyl boronic acid as an electrophile. The reaction started to form one side of PGB-0 followed by the second side. 


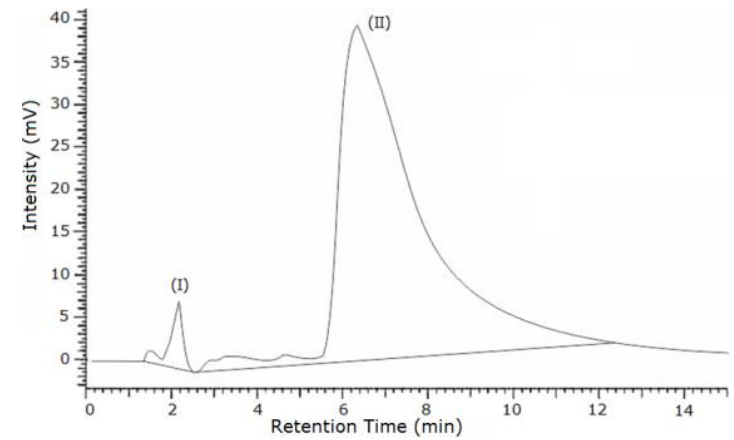

Figure 3. HPLC profile of PGB-0. The sample was running on $\mathrm{C} 18$ with mobile phase acetonitrile:water (40:60) with UV detector at wavelength $254 \mathrm{~nm}$. 4-formylphenyl boronic acid (i) and PGB-0 (ii)

\section{Cytotoxic effect of PGB-0 on MCF- 7/HER2 and NIH3T3 Cells.}

The cytotoxic assay was carried out to evaluate the cytotoxicity of PGB-0 on HER2 overexpressed-breast cancer cells and normal cells. The cytotoxic effect of PGB-0 was conducted by MT'T assay. PGB-0 inhibited cells growth of MCF-7/HER2 with an $\mathrm{IC}_{50}$ value of $270 \mu \mathrm{M}$ and performed no effect on NIH3T3 normal cells (Figure 4). The cytotoxicity of PGB-0 was possibly through cell cycle arrest or apoptosis induction.

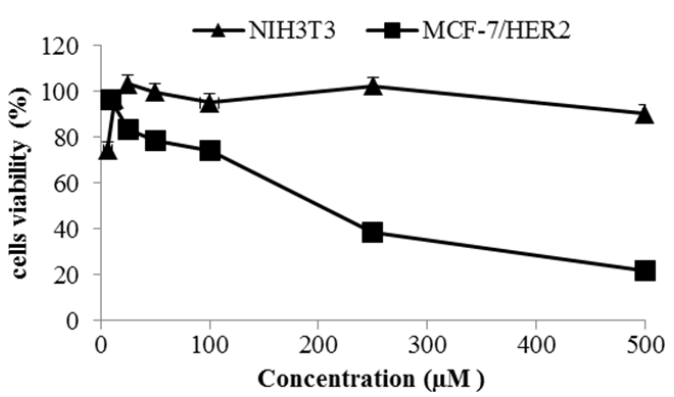

Figure 4. Cytotoxic effect of PGB-0 on NIH3T3 and MCF-7/HER2 cells. Cells viability was determined by using MT'T assay as stated in the method. The graph represented the correlation between concentration and cells viability of PGB-0. After regression analysis $(\mathrm{P}<0.05)$, we obtained $\mathrm{IC}_{50}$ of PGB-0 on MCF $7 /$ HER2 was $270 \mu \mathrm{M}$. Data expressed as the mean \pm standard error of the mean (SEM) from three independent experiments.

\section{Effect of PGB-0 on Cell Cycle Modulation}

To evaluate the cytotoxicity of PGB-0 whether caused by cell cycle arrest in MCF-7/HER2 cells, we performed flow cytometry analysis using PI staining. Cell cycle analysis revealed that PGB-0 increased cells accumulation in Sub-G1 phase (Figure 5). This phenomenon needed to be confirmed by apoptosis assay to determine sub-G1 cells accumulation due to apoptosis cells or necrosis.

A

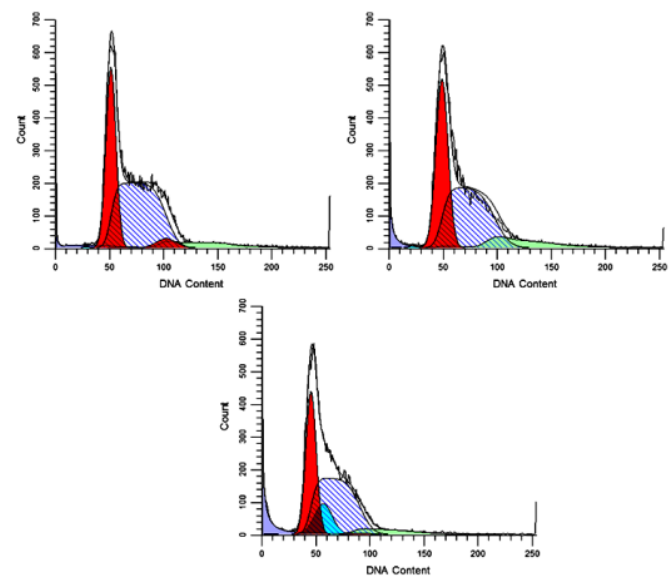

B

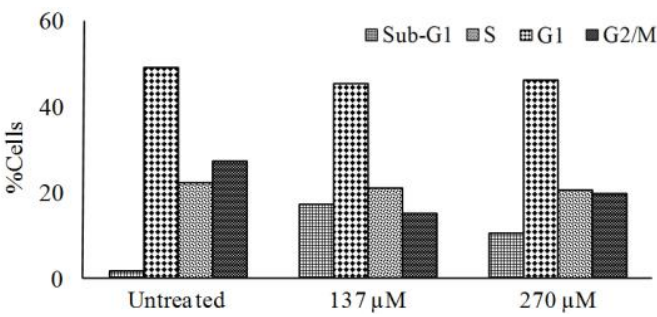

Figure 5. The Effect of PGB-0 on Cell Cycle Progression of MCF-7/HER2. Cells were seeded in 6-well, harvested after $24 \mathrm{~h}$ of treatment, stained with propidium iodide and DNA content were analyzed by using flow cytometry as described in method (A) The profiles of cells in sub-G1, G1, S and G2-M phase of (i) control, (ii) PGB-0 $135 \mu \mathrm{M}$ (iii) PGB-0 270 $\mathrm{M}$. X-axis showed the DNA content and the $\mathrm{Y}$ axis showed the relative cell numbers. (B) Quantification of cell distribution in each phase.

\section{PGB-O Decrease HER2 Expression}

We performed western blot of HER2 to confirm whether the cells growth inhibition by PGB-0 was related to HER2 expression. Based 
on results, PGB-0 50 $\mu \mathrm{M}$ did not affect HER2 expression. However, after treatment of PGB-0 $150 \mu \mathrm{M}$, HER2 expression was decreasing (Figure 6).

\section{HER2 \\ $\alpha$-tubulin \\ Untreated \\ PGB-0 50 $\mu \mathrm{M}$ \\ PGB-0 150 $\mu \mathrm{M}$}

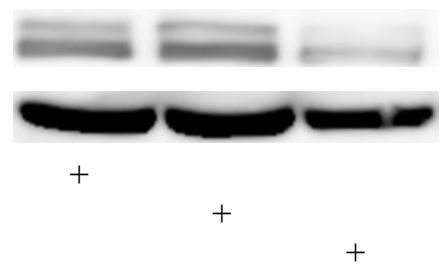

Figure 6. Effect of PGB-0 on the HER2 expression on MCF-7/HER2 cells using western blot. Cells were treated with a concentration of PGB-0 $50 \mu \mathrm{M}$ and 150 for $\mu \mathrm{M}$ $24 \mathrm{~h}$, then was analyzed using Western Blot as described in methods.

The purposes of this study are to synthesize and explore the anticancer activity of a new curcumin analogue, PGB-0 on HER2 overexpressed-cancer cells. Our screening using molecular docking PLANTS revealed that PGB-0 possibly bound to ATP binding site of EGFR and HER2. Lapatinib and Curcumin were used as a native ligand. Although $f_{P L P}$ score of PGB-0 is higher than lapatinib and curcumin, the binding distance of PGB-0 on both HER2 and EGFR is shorter than lapatinib and curcumin. Hence, we found that PGB-0 is comparable with lapatinib and curcumin to bind on ATP binding site of HER2 and EGFR based on molecular docking study. We succeed to synthesize PGB-0 with a simple method and reproducible. Synthesis strategy of PGB-0 is similar with common curcumin analogues synthesis which is based on aldol reaction. However, several factors such as mixing speed, temperature, $\mathrm{pH}$, and the presence of boric acid on PGB-0 structure need to be controlled to minimize the by-product. Boric acid easily reacts with the other boric acid to produce boroxine (Nishiyabu et al., 2011). Our result demonstrated that PGB-0 inhibited cells growth of HER2 overexpressed-cancer cells and performed no effect on normal cells. According to the $\mathrm{IC}_{50}$ values, the cytotoxicity of PGB-0 is less potent than lapatinib
$\left(\mathrm{IC}_{50}=8 \mu \mathrm{M}\right)$ and curcumin $\left(\mathrm{IC}_{50}=25 \mu \mathrm{M}\right)$ (the data was not shown). However, commonly, the requirement of chemopreventive and cochemotherapeutic agents only need a compound possessing specific target in cancer cells (Meiyanto et al., 2014). On the other hand, boron carrying pharmaceutical also requires non-cytotoxic compound to minimize the nonselective toxicity to the patient (Barth, 2005). Thus, the less cytotoxicity of PGB-0 tends to be an advantage compared to lapatinib and curcumin. Curcumin and its analogues are well known inducing G2/M arrest (Meiyanto et al., 2014) though, PGB-0 induced sub-G1 cells accumulation. Cells in sub-G1 phase were described as a hypodiploid cell with low DNA content due to the DNA fragmentation and possibly apoptotic cells. Therefore, sub-G1 accumulation induction by PGB-0 need to be confirmed by apoptosis assay.

HER2 is a transmembrane receptor that also disrupts both the intrinsic and extrinsic apoptotic pathways (Carpenter and Lo, 2013). In extrinsic pathway, HER2 suppresses the apoptosis cell in the response to TNF- $\alpha$. HER2 activates PI3K-Akt signaling then Aktmediated that leads to activation of $\mathrm{NF} x \mathrm{~B}$ to transcript anti-apoptosis protein. In the western blot, the result revealed that PGB-0 decreased the expression of HER2. This result is not the first report that curcumin and its analogues or related groups possessed activity as HER2 and tyrosine kinase inhibitor. Meiyanto et al., (2014) reported that curcumin and PGV-1 inhibit HER2 proteins, resulting in inhibition of $\mathrm{NF}$ $x \mathrm{~B}$ activation. Determination of another kinase protein related to HER2 pathway is needed to confirm the molecular mechanism of PGB-0 on HER2 overexpressed-cancer cells. Overall, this study discovered PGB-0 inhibits cells growth on HER2 overexpressed-cancer cells through induction of cells death and decreasing HER2 expression. In the near future, the role of PGB-0 on the downstream protein of HER2 and binding assay of PGB-0 on HER2 receptor is interesting to be explored further in order to develop PGB-0 as a chemotherapeutic agent and boron carrying pharmaceutical targeted on HER2 receptor. 


\section{CONCLUSION}

PGB-0 inhibits cells growth on HER2 overexpressed-cancer cells through induction of cells death and decreasing HER2 expression. Further study must be established to evaluate the molecular mechanism of PGB-0 on HER2 downstream mechanism.

\section{ACKNOWLEDGEMENT}

We would express our gratitude to Insinas 2014-2016 Grant Ministry of Research Technology and Higher Education, No. RT2014-810 and Nara Insitute of Science and Technology Japan who funded and supported this research.

\section{REFERENCES}

Barth, R.F., 2005. Boron Neutron Capture Therapy of Cancer: Current Status and Future Prospects. Clin. Cancer Res. 11, 3987-4002.

Carpenter, R.L., Lo, H.-W., 2013. Regulation of Apoptosis by HER2 in Breast Cancer. J. Carcinog. Mutagen. 2013(Suppl 7), 003

D’Amato, V., Raimondo, L., Formisano, L., Giuliano, M., De Placido, S., Rosa, R., Bianco, R., 2015. Mechanisms of lapatinib resistance in HER2-driven breast cancer. Cancer Treat. Rev. 41, 877883.

English, D.P., Roque, D.M., Santin, A.D., 2013. HER2 Expression Beyond Breast Cancer: Therapeutic Implications for Gynecologic Malignancies. Mol. Diagn. Ther. 17, 85-99.

Gibbs, J.B., 2000. Anticancer drug targets: growth factors and growth factor signaling. J. Clin. Invest. 105, 9-13.

Hong, R.L., Spohn, W.H., Hung, M.C., 1999. Curcumin inhibits tyrosine kinase activity of p185neu and also depletes p185neu. Clin. Cancer Res. Off. J. Am. Assoc. Cancer Res. 5, 1884-1891.

Meiyanto, E., Hermawan, A., Anindyajati, 2011. Translational Research in Cancer Drug
Development. Ind J Canc Chemoprev. 2, 198-210.

Meiyanto, E., Putri, D.D.P., Susidarti, R.A., Murwanti, R., Sardjiman, null, Fitriasari, A., Husnaa, U., Purnomo, H., Kawaichi, M., 2014. Curcumin and its analogues (PGV-0 and PGV-1) enhance sensitivity of resistant MCF-7 cells to doxorubicin through inhibition of HER2 and NF-kB activation. Asian Pac. J. Cancer Prev. 15, 179-184.

Mosmann, T., 1983. Rapid colorimetric assay for cellular growth and survival: Application to proliferation and cytotoxicity assays. J. Immunol. Methods 65, 55-63.

Moy, B., Goss, P.E., 2006. Lapatinib: Current Status and Future Directions in Breast Cancer. The Oncologist 11, 1047-1057.

Nishiyabu, R., Kubo, Y., James, T.D., and Fossey, J.S., 2011, Boronic acid building blocks: tools for self assembly, Chem. Commun. 47, 1124-1150

Plavetić, N.D., Kulić, A., Vrbanec, D., 2012. Role of HER2 signaling pathway in breast cancer: biology, detection and therapeutical implications. Period. Biol. 114, 505-510.

Sardjiman, S.S., Reksohadiprodjo, M.S., Hakim, L., van der Goot, H., Timmerman, H., 1997. 1,5-Diphenyl-1,4-pentadiene-3ones and cyclic analogues as antioxidative agents. Synthesis and structure-activity relationship. Eur. J. Med. Chem. 32, 625-630.

Vu, T., Claret, F.X., 2012. Trastuzumab: Updated Mechanisms of Action and Resistance in Breast Cancer. Front. Oncol. 2, 62

Yakes, F.M., Chinratanalab, W., Ritter, C.A., King, W., Seelig, S., Arteaga, C.L., 2002. Herceptin-induced inhibition of phosphatidylinositol-3 kinase and Akt Is required for antibody-mediated effects on $\mathrm{p} 27$, cyclin D1, and antitumor action. Cancer Res. 62, 4132-4141. 